DOI: $10.31933 /$ DIJEMSS

Received: $12^{\text {th }}$ August 2020, Revised: $25^{\text {th }}$ September 2020, Publish: $18^{\text {st }} 2020$

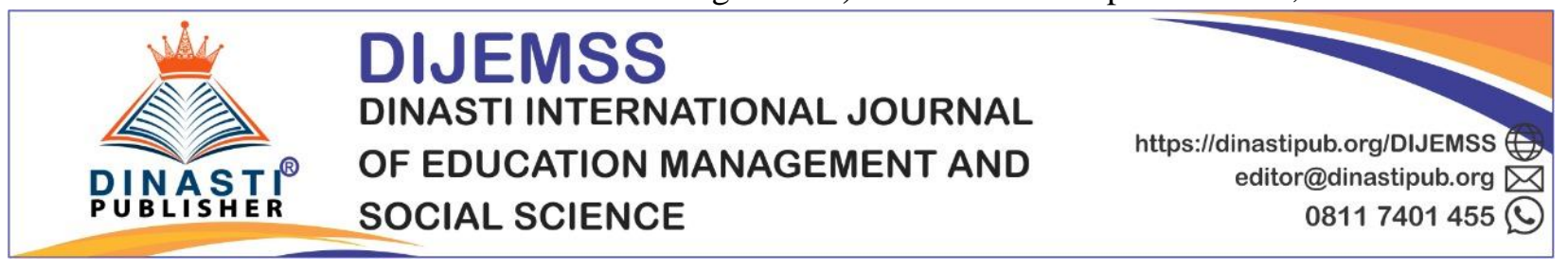

\title{
THE INFLUENCE OF TRAINING, MOTIVATION AND COMPENSATION AGAINST EMPLOYEE PERFORMANCE ON PROCUREMENT CENTER AT DKI JAKARTA
}

\author{
Siti Mukhlidah', Nur Aktif ${ }^{2}$ \\ 1) Mercu Buana University, Jakarta, Indonesia, idamukhlidah@gmail.com \\ 2) Mercu Buana University, Jakarta, Indonesia, nuraktif123@gmail.com
}

\section{Corresponding Author: Siti Mukhlidah}

\begin{abstract}
This research aims to discover and examine those influence from training, motivation and compensation towards employee performance at DKI Jakarta's Procurement Center Agency. This research method used quantitative research by causality research. The population from this research were all employee at DKI Jakarta's Procurement center with amounted of 140 people. Sample chosen through saturated sampling method. Data collection method occured by questionnaires and interviews. Data processing using SPSS Windows 25.0 software with descriptive analysis and hypothesis test to multiple linear regression analysis. The results showed that: (1) Training variable partially had positive and significant impact to employee performance at DKI Jakarta's procurement center; (2) motivation variable partially had positive and significant towards employee performance at DKI Jakarta's Procurement Center Agency; (3) Compensation variable partially had positive and significant impact to employee performance at DKI Jakarta's Procurement Center Agency; (4) There had simultaneously significant impact between each variables of training, motivation and compensation towards Employee performance at DKI Jakarta's Procurement Center Agency.
\end{abstract}

Keywords: Training, Motivation, Compensation and Employee Performance.

\section{INTRODUCTION}

Performance is a condition that recognize to find out regarding level of an achievement of organization's results. Having an effective and efficient performance measurement system is very important for purposes of developing Civil Servants and achieving performance according to its motive.

One of way that government organizations did to develop ASN capabilities is by providing intensive education and training, which aims to maximize those capabilities from its employees. Employee In a government organization are also received the training to improve individual competencies and capabilities. Training is needed to improve performance and also to anticipate 
changes in skill requirements according to technological developments. By this training, government organizations will have a State Civil Apparatus who has knowledge, abilities and skills which could improve employee performance and organization performance.

Motivation is a someone's tendency to involve themselves in activities that lead to its goals in work as satisfaction, but furthermore, its a feeling of pleasure or willingness to work and achieve that work goals. To build up performance and motivation, it is necessary to provide compensation, career paths, development of competencies as a driving force to achieve their desired performance.

Beside training and motivation, there has another factors whom affect the Apart from training and motivation, there are other factors that affect the civil servants performance, such as compensation. Compensation is remuneration that given to employees for work that has been completed. Compensation is positive perceived and adequate perceived by employee who could stimulate those employee performance, in the other hand, compensation could be perceived as negative in which felt to be inadequate to meet the needs of daily life will encourage employees to be reluctant to show their best performance. An Employee who feel that their compensation is inadequate has potential to bring out service practices with money motive. Those people who give money will be received its faster service. civil servants, namely compensation. Compensation is remuneration given to employee for work that has been completed. Compensation that perceived as positive and perceived as adequate by employees can stimulate employee performance, on the other hand, compensation that is perceived as negative and which is felt to be inadequate to meet the needs of daily life will encourage employee to be reluctant to show their best performance. Employees who felt that their compensation is inadequate has potential to carry out service practices with money motive. Those who give money will received faster service.

The performance from Procurement Center Agency at DKI Jakarta Province for last 3 (three) years has decreased, which is every year those failure from tenders has increased. Of course, organization performance cannot be separated from the performance of its human resources. Based on this phenomenon, researchers were interested to examined those relate factors that had an impact towards employee performance, with research title of "The Influence of Training, Motivation and Compensation Against Employee Performance on Procurement Center Agency at DKI Jakarta".

\section{Research Purposes}

The research supposed in accordance with problem formulation as its follows:

1) To discover those impact which come from training towards employee performance.

2) To find out the influence from motivation on employee performance.

3) To determine those affect from compensation to employee performance.

4) To find out if training, motivation, compensation had an influence together over employee performance.

\section{LITERATURE REVIEW}

\section{Employee Training}

According to Dessler (2015:284) training means providing knowledge to new employee or existing regarding which skills that they required to do their job. Meanwhile, according to Bangun 
(2015:201) training is a process to maintain or improve employee skills to produce an effective works. From this opinion above, it could be said that training was dedicated to all employee in order to increase knowledge, skills and behavior in achieving organization goals.

\section{Employee Motivation}

Robbins and Judge (2015:112) define motivation as a process that could describes people strength, direction and persistence in an effort to achieve goals. Strength (intensity) describes as how hard a person tries. Great power is unlikely to produce great performance results unless those effort lead in direction which could have benefits to organization. Persistence measures how long a person could maintain its efforts. According to Wibowo (2016:379) it suggests that motivation is an drive factor for a series of human behavior processes in achieving goals. While the elements was contained in motivation include elements of arousing, directing, maintaining, showing intensity, being continuous and having a purpose.

Based on those understanding, it could be concluded that work motivation is a stimulant of a desire and driving force of will that creates a person's excitement to achieve the desired goal. High work motivation which given by employees will increase work performance and productivity of organization, so it would facilitate those achievement from organization goals which have been set.

\section{Employee Compensation}

According to Bangun (2015:255) compensation is something that employee received for the services that they contribute to their work. They contribute to what they think has valuable, both their energy and knowledge that they have and something that is valuable for employees is knowledge and skills which they used as basis for claiming their rights as workers. According to Dessler (2015:417) employee compensation includes all forms of payment that given to employee which arises from their work related. Employee compensation has two main components, which is direct financial payments in the form of wages, salaries, incentives, commissions and bonuses, and indirect financial payments in form of insurance and vacations paid by the employer.

\section{Employee Performance}

According to Mathis and Jackson (2011:378), performance is what employee do or don't that could affects how much they contribute to organization in terms of output quality, output quantity, output duration, workplace attendance and teamwork attitude. Performance is very important in organization to achieve its goals. Performance can run well if employee get a salary that is expected, receive training and development, a conducive work environment, receive same treatment, assign employees according to their expertise and receive career planning assistance and there has feedback from organization. According to Kasmir (2016:182) performance is the result of work and work behavior that has been achieved in completing tasks and responsibilities given in a certain period. From this definition, performance implies that performance is the result from 
person's work and work behavior in period, usually 1 (one) year. Then performance could be measured by its ability to complete the tasks and responsibilities that given.

From this above opinion, it could be concluded that performance is the work of human resources (employee) who work in organization or institution guided by target that have been set in order to achieve the goals of the organization.

\section{Theoretical Framework}

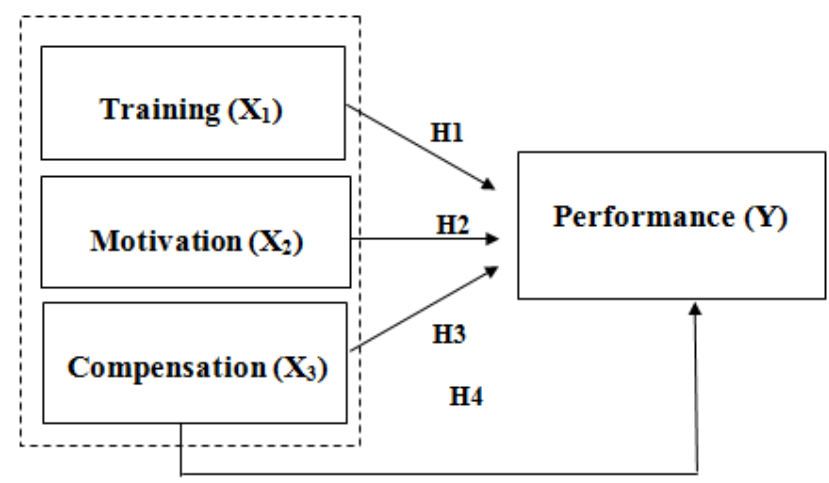

Figure 1. Theoretical Framework

\section{Research Hypothesis}

Based on theoretical review and theoretical framework, this following research hypothesis can be formulated as in belows:

1) Training had an impact towards employee performance on Procurement Center Agency at DKI Jakarta Province

2) Motivation had an influence towards employee performance on Procurement Center Agency at DKI Jakarta Province.

3) Compensation had an impact towards employee performance on Procurement Center Agency at DKI Jakarta Province

4) Training, Compensation and Motivation jointly had an affect to employee performance on Procurement Center Agency at DKI Jakarta Province

\section{RESEARCH METHODS}

\section{Types of Research}

This research used quantitative research with causality approach which aims to find a causal relationship between independent variables (variables that affect) and dependent variables (which are influenced). (Now \& Bougie, 2017: 112). 


\section{Operational Definition and Variable Measurement}

To complement the data which carried out from this research, the researcher created a variable operational definition table used to complete the questionnaire which is presented in table below:

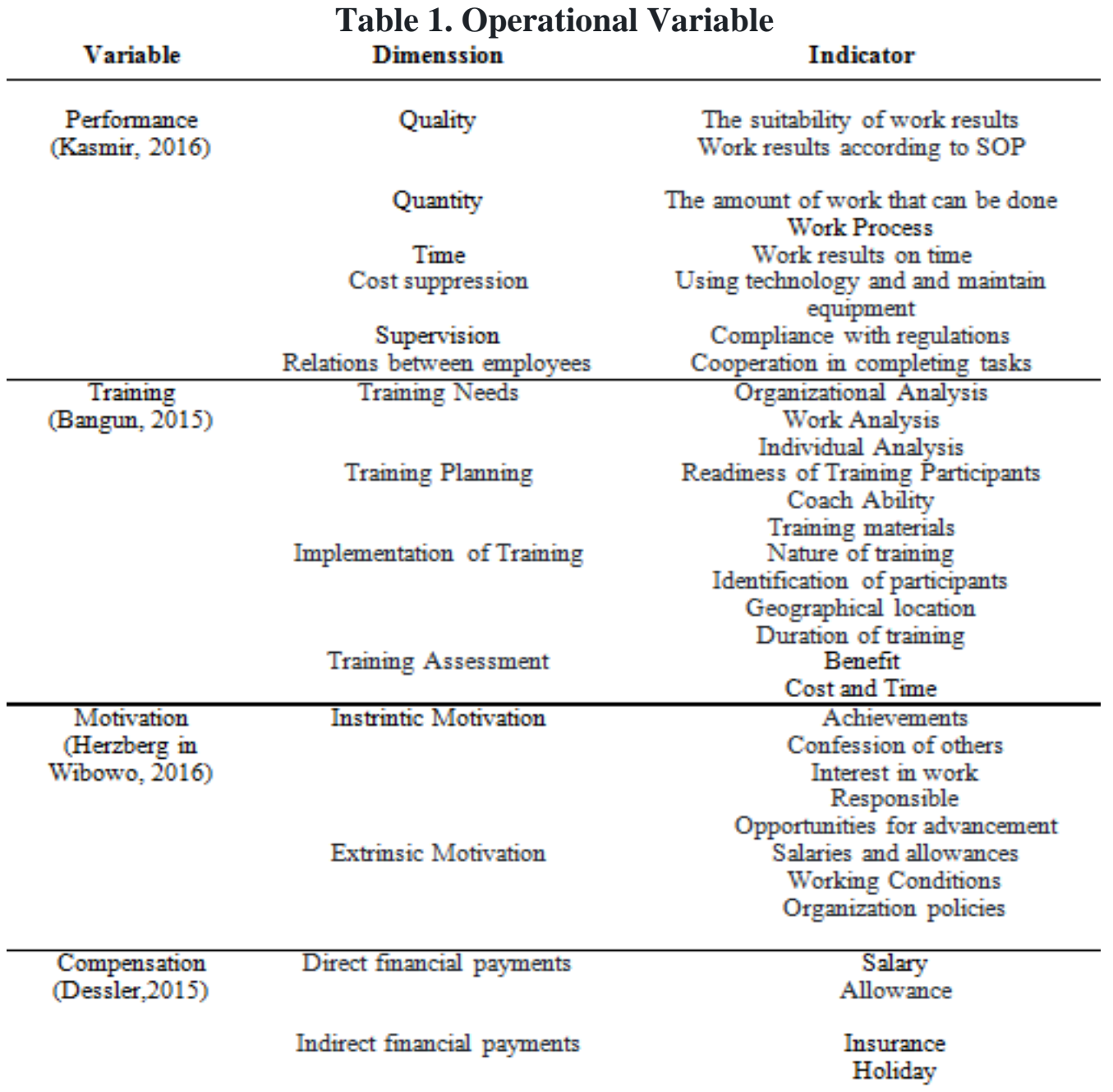

\section{Population and Sample}

Population is a group of people, events, or interesting stuff where the researcher wants to make an opinion based on sample statistics (Sekaran \& Bougie (2017:53). The population from this research were all Civil Servants from Procurement Center Agency which numbered of 140 (one hundreds and fourty) people.

The sample was part of total characteristics from population under research (Sugiyono 2016:58). Sampling used the Cosensus technique that used all samples. This was often occured when population was relatively small or research makes generalizations with very few errors. Another term for saturated sample is Consensus (Sugiyono 2016:59). Therefore, the number of 
samples as corresponds in this research according to total population on Procurement Center Agency at DKI Jakarta which total of 140 people.

\section{Data Collecting Methods}

Data collection methods used here were questionnaires, interviews, and field studies or observations. The questionnaire is a data collection technique that is done by giving a set of questions or written statements for respondent to answer. The data obtained from the questionnaire were used as primary data in this research while The questionnaire that contains an assessment from variables of training, motivation, compensation and employee performance at DKI Jakarta's Procurement Service Agency. This assessment used a Likert scale model, which is by setting the weight and then adding it to get a number of each indicator measured.

\section{Data Analysis Method}

This research was examined by multiple linear regression models with help from SPSS software program. Before doing multiple linear regression test, these data from questionnaire answers were first tested for validity and reliability. Then after its declared valid and reliable, so continued with classic assumption test, which includes the normality test, multicollinearity and heteroscedasticity, which then after classical assumption test fulfilled, a multiple linear regression test could be carried out. The relationship between independent variables and dependent variable could be described through this following multiple linear regression equation: $\mathrm{Y} 1=\alpha+\beta 1 \mathrm{X} 1+\beta 2 \mathrm{X} 2+\beta 3 \mathrm{X} 3$

To prove this hypothesis, the following steps were taken: Hypothesis test with t test and $\mathrm{F}$ test. The use of $t$ test and $F$ test in this research was to find out how much influence that earned from each independent variable towards dependent variable and how much influence that independent variable had to dependent variable if it was carried out simultaneously. Hypothesis test with t-test used to determine whether independent variable was significant towards dependent variable with those level of confidence selected at 5\% level $(\alpha=0.05)$.

\section{RESULT AND DISCUSSION \\ Characteristics of Respondents}

Total respondents that used in this research were 137 employees from Procurement Center Agency at DKI Jakarta. Based on data gathered, its known that male respondents were more than female respondents. This result because 102 respondents $(72.85 \%)$ stated that they were male, and remaining of 38 respondents (27.15\%) were female. Respondents Based on age, it could be seen that most of respondents were in > 36 years old category, which is 119 respondents (85\%). Respondents based on education, it was known that 15 respondents $(10.7 \%)$ have a high school education, 8 (5.7\%) Diploma 3, 97 respondents (69.3\%) have an undergraduate education and 20 respondents (14.3\%). \%) stated that they had Postgrade education. Meanwhile, the highest number of respondents' tenure was 88 respondents $(62.8 \%)$ who stated that they had a working period for 
more than 20 years, followed by respondents who had tenure of 10-20 years, which is 39 respondents $(27.9 \%)$ and 13 respondents $(9.3 \%)$ had worked less than 10 years.

Thus it could be concluded that majority of employees on Thus it can be concluded that the majority of employees from Procurement Center Agency at DKI Jakarta were males aged > 36 years and had an undergraduate educational background with work period for more than 20 years. This encourage the research so the data which obtained was correct according to conditions at DKI Jakarta's Procurement Center Agency.

\section{Classic Assumption Test}

Normality Test

The normality test in this research used Kolmogorov-Smirnov test using significant level of 0.05. Data were declared to be normally distributed if they were significantly greater than 5\% (> 0.05). The results from normality test could be explained based on this table below.

Table 2. Normality Test Result

One-Sample Kolmogorov-Smirnov

\begin{tabular}{|c|c|c|}
\hline & & $\begin{array}{c}\text { Unstandardize } \\
\text { d Residual }\end{array}$ \\
\hline \multicolumn{2}{|l|}{$\mathrm{N}$} & 140 \\
\hline \multirow{2}{*}{ Normal Parameters ${ }^{a, b}$} & Mean & 0,0000000 \\
\hline & Std. Deviation & 5,33609422 \\
\hline Most Extreme & Absolute & 0,075 \\
\hline \multirow[t]{2}{*}{ Differences } & Positive & 0,075 \\
\hline & Negative & $-0,041$ \\
\hline Test Statistic & & 0,075 \\
\hline Asymp. Sig. (2-tailed) & & $.050^{c}$ \\
\hline
\end{tabular}

From this normality test results, it could be seen that significant value for unstandardized residuals was 0.50 . This value was significant than unstandardized variable residuals which is greater than 0.05 , So it could be concluded that data in regression model was normally distributed.

\section{Multicollinearity Test}

A good regression model which there is no correlation between the independent variables. It could be seen by looking at value of inflation factor (VIF) and tolerance in regression model. If the VIF value was less than 10 and tolerance for more than 0.1 then regression model is free of multicollinearity. The multicollinearity test results could be explained based on table below.

Table 3. Mulicolinearity Test Result

\begin{tabular}{clrc}
\hline No & \multicolumn{1}{c}{ Variable } & Tolerance & VIF \\
\hline 1. & Transformational Employee & 0,482 & 2,075 \\
& Training & 0,415 & 2,409 \\
2. & Employee Motivation & 0,445 & 2,245 \\
3. & Employee Compensation & & \\
\hline
\end{tabular}


Based on multicollinearity test result, it is known that employee training, employee motivation and employee compensation had VIF values $<10$ and tolerance values $>0.1$. This could be means that this regression model was free from multicollinearity.

\section{Heteroscedasticity Test}

This test was conducted by scatterplot regression model with condition that the dots spread out with unclear pattern above and below the number 0 on the $\mathrm{Y}$ axis, so there is no heteroscedasticity problem.

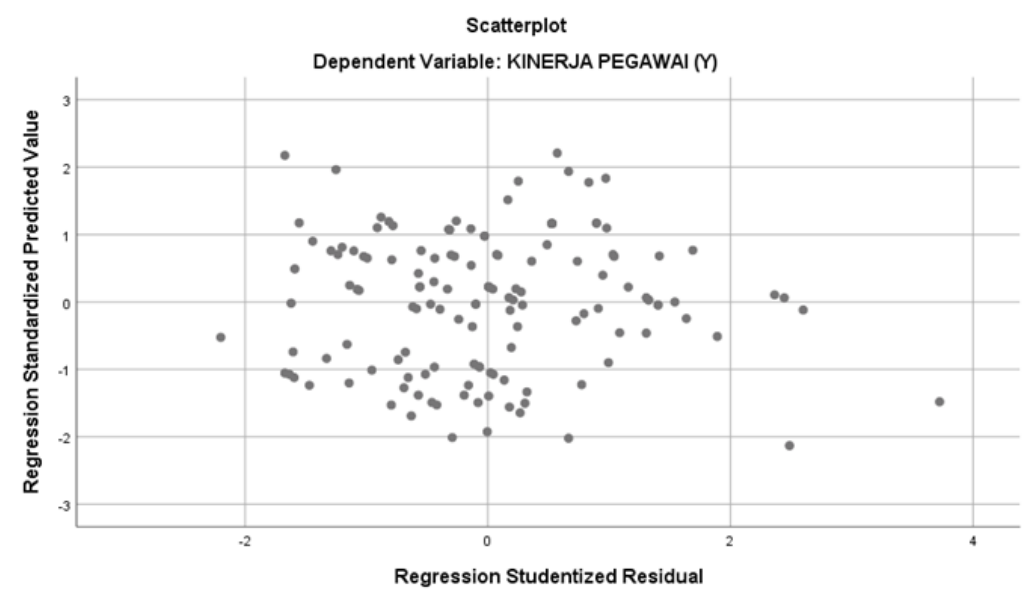

Figure 2. Heteroscedasticity Test Result

From scatterplot test results, it could be seen that the dots spread with unclear pattern above and below the number 0 on the $\mathrm{Y}$ axis. These results was indicated that there is no heteroscedasticity problem in this regression model.

\section{Multiple Regression}

The results from classical assumptions test in this research was indicated that there's no problems with residual normality, there were no problems with multicollinearity and have no problems with heteroscedasticity. Thus this research could be carried out because the data met the criteria to conducted multiple linear regression analysis.

Table 4. Multiple Regression Analysis

\begin{tabular}{|c|c|c|c|c|c|c|c|c|}
\hline \multicolumn{9}{|c|}{ Coefficients $^{a}$} \\
\hline & & \multicolumn{2}{|c|}{$\begin{array}{l}\text { Unstandardized } \\
\text { Coefficients }\end{array}$} & \multirow{2}{*}{$\begin{array}{c}\begin{array}{c}\text { Standardiz } \\
\text { ed } \\
\text { Coefficient } \\
\text { s }\end{array} \\
\text { Beta }\end{array}$} & \multirow[b]{2}{*}{$t$} & \multirow[b]{2}{*}{ Sig. } & \multicolumn{2}{|c|}{ Collinearity Statistics } \\
\hline \multicolumn{2}{|l|}{ Model } & $B$ & Std. Error & & & & Tolerance & VIF \\
\hline \multirow[t]{4}{*}{1} & (Constant) & 2.762 & 4.162 & & 5.949 & 0.000 & & \\
\hline & PELATIHAN KEPEGAWAIAN (X1) & 0.207 & 0.081 & 0.007 & 0.801 & 0.035 & 0.482 & 2.075 \\
\hline & MOTIVASI PEGAWAI (X2) & 0.415 & 0.098 & 0.390 & 4.236 & 0.000 & 0.415 & 2.409 \\
\hline & KOMPENSASI PEGAWAI (X3) & 0.301 & 0.070 & 0.384 & 4.319 & 0.000 & 0.445 & 2.245 \\
\hline
\end{tabular}


Based on regression output above, the regression equation was obtained as follows: $\mathrm{Y}=2.762+0.207 \mathrm{X} 1+0.415 \mathrm{X} 2+0.301 \mathrm{X} 3$

\section{Hypothesis Examination}

\section{Partial Test (t test)}

The regression results from employee training variable to employee performance resulted in $\mathrm{t}$ value of 0.801 and significance value of 0.035 . The result of $\mathrm{t}$ value obtained was greater than $\mathrm{t}$ table $(0.801>0.159)$ and significance value was less than $0.05(0.035<0.05)$. Thus it could be concluded that employee training partially had significant influence over employee performance.

For employee motivation variable, $t$ value is 4,236 with significance value of 0,000 . The result from $t$ count value obtained was greater than t table $(4.236>0.159)$ and significance value less than $0.05(0.000<0.05)$. So It could be said that employee motivation partially had significant impact towards employee performance.

Meanwhile, the employee compensation variable produced t value of 4,319 with significance value of 0,000 . The result of $t$ value that obtained was greater than t table $(4,319>0.159)$ and with significance value less than $0.05(0,000<0.05)$. It could be concluded that employee compensation partially had significant impact towards employee performance.

\section{Simultaneous Test (F Test)}

This examined used to discover those impact from independent variables together towards dependent variable. This examination from this model could be explained by variance analysis (ANOVA).

\section{Table 5. F Test Result}

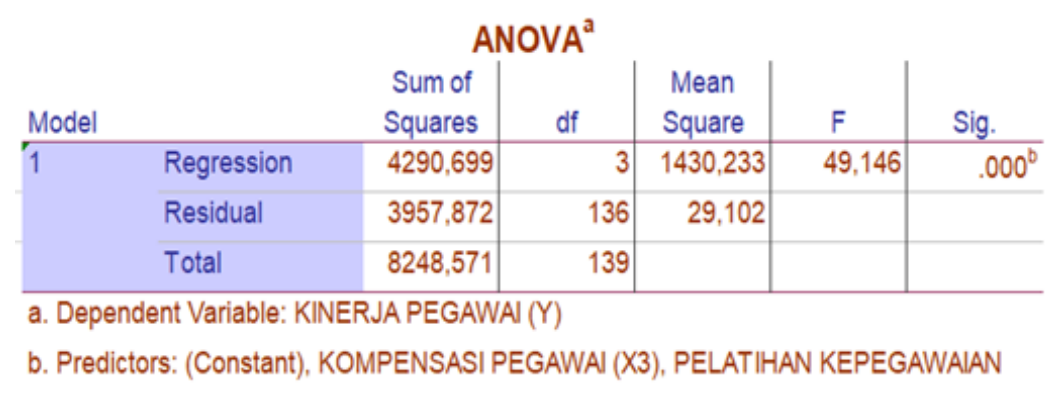

The results from this calculation obtained F count $>\mathrm{F}$ table $(49.146>2.67)$ with significance level from employee training, employee motivation and employee compensation variables was $0.000<0.05$. Thus it could be concluded that there had simultaneously significant influence between employee training, employee motivation and employee compensation on employee performance. 


\section{Determination Coefficient (Adjusted $\mathbf{R}^{2}$ )}

The coefficient of determination used to find out how much influence from independent variables simultaneously affect dependent variable. $\mathrm{R}^{2}$ value has an interval between 0 to $1\left(0<\mathrm{R}^{2}\right.$ $<1)$.

Table 5. Determination Test Result

\begin{tabular}{|c|c|c|c|c|}
\hline \multicolumn{5}{|c|}{ Model Summaryb } \\
\hline Model & $\mathrm{R}$ & R Square & $\begin{array}{l}\text { Adjusted } \\
\text { R Square }\end{array}$ & $\begin{array}{c}\text { Std. Error } \\
\text { of the } \\
\text { Estim ate }\end{array}$ \\
\hline 1 & $.721^{a}$ & 0.520 & 0.510 & 5.395 \\
\hline \multicolumn{5}{|c|}{ a. Predictors: (Constant), KOMPENSASI PEGAWAI (X3), } \\
\hline \multicolumn{5}{|c|}{ b. Dependent Variable: KINERJA PEGAWAI (Y) } \\
\hline
\end{tabular}

According to the table above, Adjusted $\mathrm{R}^{2}$ value was $0.510(51 \%)$. This shows that employee performance shaped by training, motivation and compensation by $51 \%$. While the remaining $49 \%$ was any influenced by other variables outside this research.

\section{Inter-Dimensional Correlation}

Two variables were said to be correlated when changes in one variable would accompanied by the others, either in the same direction or the opposite one. Correlation between dimensions was shown in this table below:

Table 6. Inter-Dimensional Correlation Result

\begin{tabular}{|c|c|c|c|c|c|c|c|}
\hline \multicolumn{8}{|c|}{ Correlations } \\
\hline \multirow[b]{2}{*}{ Variabel } & \multirow[b]{2}{*}{ Dimensi } & \multicolumn{6}{|c|}{ Kinerja Pegawai $(\mathrm{Y})$} \\
\hline & & $\begin{array}{c}\text { Kualitas } \\
\text { (Y1) }\end{array}$ & $\begin{array}{c}\text { Kuantitas } \\
\text { (Y2) }\end{array}$ & $\begin{array}{l}\text { Ketepatan } \\
\text { Waktu (Y3) }\end{array}$ & $\begin{array}{c}\text { Pendekatan } \\
\text { Biaya (Y4) }\end{array}$ & $\begin{array}{c}\text { Pengawasan } \\
\text { (Y5) }\end{array}$ & $\begin{array}{c}\text { Hubungan } \\
\text { antar Pegawai } \\
\text { (Y6) }\end{array}$ \\
\hline \multirow{4}{*}{$\begin{array}{c}\text { Pelatihan } \\
\text { Kepegawaian } \\
\text { (X1) }\end{array}$} & $\begin{array}{l}\text { Kebutuhan } \\
\text { Pelatihan (X1.1) }\end{array}$ & 0.322 & 0.436 & 0.487 & 0.643 & 0.464 & 0.464 \\
\hline & $\begin{array}{l}\text { Perencanaan } \\
\text { Pelatihan (X1.2) }\end{array}$ & 0.556 & 0.261 & 0.327 & 0.34 & 0.272 & 0.277 \\
\hline & $\begin{array}{l}\text { Pelaksanan } \\
\text { Pelatihan (X1.3) }\end{array}$ & 0.301 & 0.365 & 0.300 & 0.497 & 0.401 & 0.295 \\
\hline & \begin{tabular}{|l} 
Penilaian \\
Pelatihan (X1.4)
\end{tabular} & 0.379 & 0.41 & 0.422 & 0.485 & 0.275 & 0.253 \\
\hline \multirow{2}{*}{$\begin{array}{c}\text { Motivasi } \\
\text { Pegawai (X2) }\end{array}$} & $\begin{array}{l}\text { Motivasi } \\
\text { Instrinsik (X2.1) }\end{array}$ & 0.325 & 0.419 & 0.948 & 0.458 & 0.295 & 0.360 \\
\hline & $\begin{array}{l}\text { Motivasi } \\
\text { Ekstrinsik (X2.2) }\end{array}$ & 0.528 & 0.416 & 0.485 & 0.71 & 0.469 & 0.385 \\
\hline \multirow{2}{*}{$\begin{array}{l}\text { Kompensasi } \\
\text { Pegawai }(X 3)\end{array}$} & $\begin{array}{l}\text { Pembayaran } \\
\text { Finansial } \\
\text { Langsung (X3.1) }\end{array}$ & 0.435 & 0.455 & 0.459 & 0.602 & 0.54 & 0.485 \\
\hline & $\begin{array}{l}\text { Pembayaran } \\
\text { Finansial Tidak } \\
\text { Langsung (X3.2) }\end{array}$ & 0.455 & 0.468 & 0.448 & 0.448 & 0.363 & 0.257 \\
\hline
\end{tabular}


Based on those table above, it could be seen that correlation value from SPSS calculation was positive and the large dimension values were obtained from each dimension, such as:

1) From Employee Training Variables, the dimension with strongest correlation was Training Needs (X1.1) to Cost Approach (Y4) with coefficient value $=0.643$

2) From Employee Motivation variable, the dimension with strongest correlation is Instrinsic Motivation (X2.1) to punctuality (Y3) with coefficient value $=0.948$,

3) From Employee Compensation variable, the strongest dimension was Direct Financial Payment (X3.1) to Cost Approach (Y4) with coefficient value $=0.602$.

\section{CONCLUSION AND SUGGESTION}

\section{Conclusion}

1) Employee training partially had positive and significant influence towards Employee Performance on XYZ Agency, which is dominated by training needs that have a high correlation which capable to improve employee performance.

2) Employee Motivation partially had positive and significant impact on Employee Performance in fact which more motivated the employee, will result to the higher of employee performance value.

3) Compensation had significant positive impact towards employee performance which is dominated by direct financial payments that have the strongest influence.

4) Employee Training, Employee Motivation and Employee Compensation simultaneously had significant influence over Employee Performance. These results was indicated that these three independent variables as a whole contribute to improving employee performance.

\section{Suggestion}

1) Training is one of way to applied those employee competency development. It Could be carried out independently by internal government agency or together with other government agencies that have accreditation for development of certain competencies. Therefore, the Procurement center Agency should created Training Needs Assessment (TNA) or an effective and efficient the needs analysis. In particular, training for the functional employee on procurement center which are the main performance indicators for training and Development of Human Resources.

2) It is recommended that BPPBJ leaders should continue to motivate their employees to improve their performance by creating activity programs that could encourage the employee morale so they put their duties as mandate which could accounted for. This activity could be in form of a Group Discussion Forum (FGD) of each assignment and function, a coffee break after Monday morning briefing or spiritual guidance once a month between working time.

3) Compensation seen as something that employees really hope will not be able to satisfy all employees because of different levels of needs. However, in this case, DKI Jakarta's Procurement Center needs to conduct research proved that compensation in form of regional 
performance allowance that received by goods/service managers was not fit to the workload and level of risk that experienced, and suggested additional value to Regional Head.

4) In arranging the annual Performance Plan (Renkin) and Budget Activity Plan (RKA), it is recommended that BPPBJ should created training, coaching, and employee performance evaluation programs as performance indicators and targets that must be achieved by each sector / division that concerned.

\section{REFERENCES}

Bangun, Wilson. (2015). Manajemen Sumber Daya Manusia. Erlangga. Jakarta

Dessler, Gary. (2015). Manajemen Sumber Daya Manusia. Salemba Empat. Jakarta.

Kasmir. (2016). Manajemen Sumber Daya Manuasia (Teori dan Praktik). Raja Grafindo Persada. Depok

Mathis, Robert L. dan Jackson, John H. (2011). Human Resources Management.Salemba Empat. Jakarta.

Robbins, S. P., dan Judge, Timothy A. (2015). Perilaku Organisasi Edisi Enam Belas Salemba Empat. Jakarta.

Sekaran, Uma. (2017), Metodologi Penelitian Untuk Bisnis, Salemba Empat

Sugiyono. (2016). Metode Penelitian Pendidikan (Pendekatan Kuantitatif, Kualitatif, dan R\&D). Bandung: Alfabeta.

Wibowo. (2016). Manajemen Kinerja ((edisi 5). Rajawali pers. Depok. 